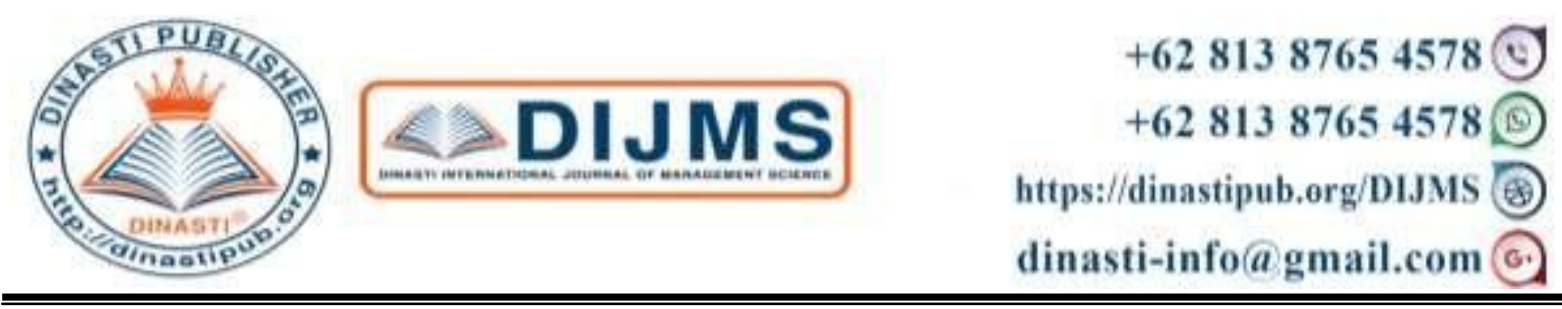

\title{
WORK - LIFE BALANCE AND ENGAGEMENT AS PARAMETERS ON MILLENNIAL TEACHERS' WORK PERFORMANCE
}

Juliana $^{1}$, Johan ${ }^{2}$

1) Pelita Harapan University, Jakarta, Indonesia

2) Pelita Harapan University, Jakarta, Indonesia

\begin{tabular}{|c|c|}
\hline $\begin{array}{l}\text { ARTICLE INFORMATION } \\
\text { Received: } 15 \text { February } 2020 \\
\text { Revised: } 25 \text { February } 2020 \\
\text { Issued: } 7 \text { March } 2020 \\
\text { (filled in by Editor) } \\
\text { Corresponding author: } \\
\text { E-mail: } \\
\text { julia52526@gmail.com }\end{array}$ & $\begin{array}{l}\text { Abstract: The purpose of this research is to analyze } \\
\text { the effects of work - life balance and employee } \\
\text { engagement on the millennial teachers' work } \\
\text { performance in Jakarta area. The data collection wa } \\
\text { being collected by having questionnaires sent to } 100 \\
\text { millennial teachers who work in formal and informa } \\
\text { educational institutions. This research used } \\
\text { quantitative method and SmartPLS } 3.2 .7 \text { software was } \\
\text { being used to evaluate the outer and inner model. The } \\
\text { results indicate that there is a negative significan } \\
\text { effect of work - life balance on the teachers' work } \\
\text { performance and there is no effect of employee } \\
\text { engagement on work performance. } \\
\text { Keywords: Work Life Balance, Engagement, Work } \\
\text { Performance, Millennial Teachers }\end{array}$ \\
\hline
\end{tabular}

\section{INTRODUCTION}

According to the Central Bureau of Statistics (BPS), 33, 75\% of the entire Indonesian populations are millennial generations or anyone born between the year of 1981 and 1996. This percentage indicates that out of $67 \%$ Indonesians who are now in their productive age, around $50,36 \%$ of them are millennial based on the population census data obtained in 2018 and the number is predicted to rise by the time the 2020 national census is being held (Republika, 2020). This condition leads the nation to what is expected to be a demographic bonus or a condition where the population size of people in their productive age surpass expectations and becomes larger than the population of people in their non - productive age. Simply put, the labor force of people in their productive age is higher than ever and this condition provides opportunity for increased economy and productivity (Suryahadi et.al., 2012). 


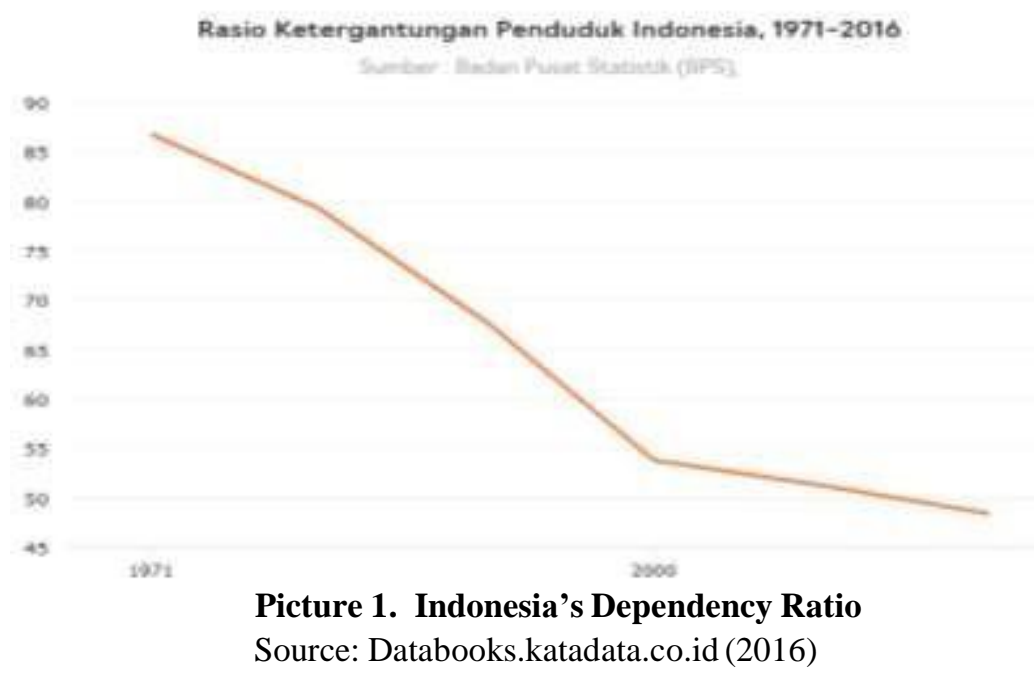

The dependency ratio obtained from the Central Bureau of Statistics (BPS) back in 2016 had already shown a trend of demographic bonus where it was estimated for every 100 people in their productive age, they would carry the burden of only 48 to 49 non - productive age citizens. With this growing trend it is expected that the country will be able to tap into the benefits of the demographic bonus since the condition is most likely could boost the country's economy and improve the welfare of its citizens. However, this golden opportunity does not go hand-in-hand with today's working world where it poses such pressing amount of stress and pressure on many employees as it has never seen before. Mental health issues among millennial generations has shown a notable increase in percentage within just five years in Indonesia as stated by the Indonesian Ministry of Health on their Basic Health Research (Riskesdas) conducted in 2018, with 9.8 percent young Indonesians in the millennial age group experiencing mental health problems, an increase from 6.1 percent back in 2013 (Kemenkes, 2018). Based on an article from CNN Indonesia (2018), a survey conducted on 4500 respondents showed that millennial workers are the most prone to work stress compared to other age groups. A survey conducted by Jobstreet.com came back with the whopping result of $85 \%$ respondents stating that their work - life balance is very low and the imbalance between their personal and work life had made them having trouble sleeping at night (Jobstreet, 2014). Another survey conducted by Future Workplace found that lack of work - life balance came out as the most top answers given by employees when being asked the reasons why they would quit a certain job even with lucrative salaries being offered (Businesswire, 2017). Millennial generations own such unique disposition on work - life balance and how they value WLB over job ranks and progression toward the company ladder (Jenkins, 2018). Striking a sense of balance between one's work and personal life has been an ongoing concern in most business sectors and educational field falls under no exception of the dilemma. A recent study conducted by Dale Carnegie Indonesia came back with some disheartening results which showed only $25 \%$ of Indonesian millennial workers have work engagement (Youngster.id, 2017). According to Pandey and Jha (2015), teachers hold an integral role in providing good quality of education, a sector of which the organizations are heavily dependent on their employees which are the teachers. Since teachers spend in average 
one - third of their time every day at work, their quality of life becomes one of the many aspects that needs to be better examined (Ahmad, 2013). Teachers' work performance plays a crucial role in their students' education and helps nurture the young minds and thus, making the profession as one of the most respected professions in the society (Parma et.al., 2014). A commitment given by organizations that is shown by their initiatives in seeking ways to increase their teachers' morale and job satisfaction will help them improve their retention rates and their ability to recruit new, skilled and valuable teachers (Capelli, 2014).

The research gap that this research attempts to fill is the discrepancies shown by some previous research related to work - life balance, engagement and work performance. There was a significant effect from employee engagement to work performance found in studies conducted by Ramadhan and Sembiring (2014) and Yudi et. al., (2017). However, these results contradict with the research result of Joushan et. al., (2015) who found no significant effect of employee engagement on their work performance. Ischevell et. al., (2016) found that work - life balance has a positive and significant effect on work performance but a different finding was established by Asima and Nilawati (2016) who found no significant effect from work - life balance to work performance. In order to fill in the gaps mentioned above, this research aims to seek and examine the impacts of work - life balance and employee engagement on work performance specifically among the millennial teachers.

\section{LITERATURE REVIEW}

Work - life balance (WLB) could be defined as the existence of synergy between one's personal life and work and how the balance between the two aspects will contribute to the improvement of quality and complement each other (Kishino and Hirano, 2016). Work life balance in organizations involve resources which are centered on health and care as well as the employee's well - being as shown from giving employees more flexible working hours, having a daycare center for the employees' children and more balanced workload among its employees (Robbins and Coulter, 2010). Minimum conflicts and balanced roles between work and personal life of an individual are usually good indicators for work - life balance (Deivasigamani and Sankar, 2014). The individual's perception of the life roles that they play on a daily basis and how well they juggle the balancing act between their personal and work life could be defined as work - life balance (Haar, Russo, Sune \& Ollier Malaterre, 2014).

Many organizations are still facing challenges in managing their employees' issue related to work - life balance (Zhang et. al., 2012). Negative consequences such as the decline of employee's health and well-being together with the decrease of company's work performance are being brought upon by the poor execution of work - life balance or WLB (Shaffer et. al., 2016). High level of stress is most likely caused by lack of balance between work and personal life and if being left unchecked, the condition will lead to high company turnover (Kumara and Fasana, 2018). Any organization that is able to embrace work - life balance (WLB) of its employees by ensuring supporting policies related to work - life balance would have a bigger chance at improving productivity and lowering the turnover rate (Helmle

et.

al.,

2014). 
Work - life balance (WLB) plays a role as one of the contributing factors in affecting the employee's engagement (Benito - Osario et. al., 2015) and one of the most essential aspects being considered by organizations to maintain their performance and retention rates is the work - life balance management (Au and Ahmed, 2014). One of the first pioneers in proposing the concept of employee engagement, Kahn (1990) posed an idea of engagement as utilizes one's self to their roles at their work place and how that individual freely expresses himself emotionally and cognitively in terms of their work roles. Members of any organizations with a sense of attachment to their roles at work and make use of the sentiments to better articulate themselves when performing their tasks are considered to have employee engagement (Abdallah et.al.,2017). Working with colleagues in order to improve work performance is something that an engaged employee will be doing without any force from the organization (Jose and Mampilly, 2012; Abraham, 2012). Positive organizational outcomes are more likely to be achieved by employees with work engagement and these outcomes include low turnover intention and increased level of productivity and satisfaction (Joo and Lee, 2017).

Effort and positive work engagement of the employees are contributing factors to the company's productivity (Musgrove and Ellinger, 2014) with the employee engagement being defined as a state or condition whereas an individual working in a company experiences passion and sense of commitment when doing his or her job (Maylett and Winner, 2014). Work performance could be defined as a set of values that affects the employee's contributions to his or her company and these values will eventually have an impact on the employees' behavior when performing or completing their tasks (Colquitt, Lepine and Wesson, 2015). Previous research found that work - life balance significantly affects work performance (Sidik, 2019; Nurwahyuni, 2019). Based on a study conducted in accredited high schools around Jakarta, the main indicator which contributed to the teachers' work performance is employee engagement (Arifin et. al., 2014). Another study supported the hypothesis that work - life balance has a significant positive relationship on workperformance which was conducted by Thevanes and Mangaleswaran (2018) and employee engagement has a significant effect on work performance (Anitha, 2014). Similar finding was also found by Azizah and Gustomo (2015) with their research found a significant effect of employee engagement on work performance.

Based on these previous findings from other research, the hypotheses are built as follows:

H1: There is a significant impact of work - life balance on work engagement

$\mathrm{H} 2$ : There is a significant impact of employee engagement on work engagement

\section{RESEARCH METHODS}

In order to study the impacts of work - life balance and employee engagement on the work performance of millennial teachers, a survey questionnaires were being used in this research. Purposive sampling method was being used and the eligible teachers who could participate and fill in the questionnaire forms are those whose age is in the range between 19 to 39 years old or those are still considered as millennial generations and work in Jakarta 
area. The data collection was being derived from the respondents between December 2019 and January 2020. In terms of measurements, the work - life balance dimensions were being modified based on the indicators developed by Tsai et. al., (2016), Chan (2015), Bhatnagar (2014) and Skinner and Chapman in Zhang et. al., (2015) consist of working hours, work load and burnout, work arrangements, leadership and reward. The key constructs on work performance are being identified using the frameworks from Schepers (2011), Audrey and Patrice (2012) and Koopmans et.al.,(2014). The scale being used for the employee engagement was based on the modification of Kourdi (2009) which consist of equity, sense of achievement, camaraderie, economic aspect and psychological aspect. SmartPLS software was being used to analyze the research data. Convergent and discriminant validity were being tested with the minimum score of 0.70 for the convergent validity results and Fornell Larcker criterion was being used as the tool to check if the discriminant validity passes the minimum requirements. AVE score that is recommended for exploratory research needs to be higher than 0.5 (Ghozali and Latan, 2015). Composite reliability needs to have a minimum score of 0.6 in order to pass the requirements and the hypotheses being tested using probability value and $\mathrm{t}$ - test as well as the coefficient determinant to see the impacts of each variable in this research. It is conducted in order to the difference in the data mean or to seek if there is an impact of exogenous variable on endogen variable (Sugiyono, 2016). Outer loading scores needs to reach 0.70 with the minimum of 0.6 score is still considered acceptable and rule of thumb of composite reliability is in the range between 0.6 to 0.7 for explanatory research and above 0.7 for confirmatory research and multicolinearity test is being done by calculating the variance inflation factor (VIF) and the score needs to be lower than 5 in order for the data to pass the tests (Ghozali and Latan, 2015).

\section{FINDINGS AND DISCUSSIONS}

The descriptive statistic of this research is as explained below:

Table 1. Sample Descriptions

\begin{tabular}{llcl}
\hline Category & & $\begin{array}{c}\text { Respondents } \\
(\mathbf{n = 1 0 0})\end{array}$ & Percentage \\
\hline Age & $18-24$ & 24 & $24 \%$ \\
& $25-31$ & 62 & $62 \%$ \\
& $32-39$ & 14 & $14 \%$ \\
\hline Years of working & $1-3$ years & 29 & $29 \%$ \\
experience & 4-6 years & 44 & $44 \%$ \\
& $7-10$ years & 22 & $22 \%$ \\
& $>10$ years & 5 & $5 \%$ \\
\hline Time being spent & $<8$ hours & 80 & $80 \%$ \\
at work & $>8$ hours & 20 & $20 \%$ \\
\hline Working & Formal institutions & 85 & $85 \%$ \\
institutions & Non - formal & 15 & $15 \%$ \\
& institutions & & \\
\hline
\end{tabular}

Source: Research Data 
The final framework from Structural Equation Modeling using SmartPLS is shown as below with item loading less than 0.5 was being removed from the calculation.

\section{Diagram 1. Structural Equation Modeling Framework.}

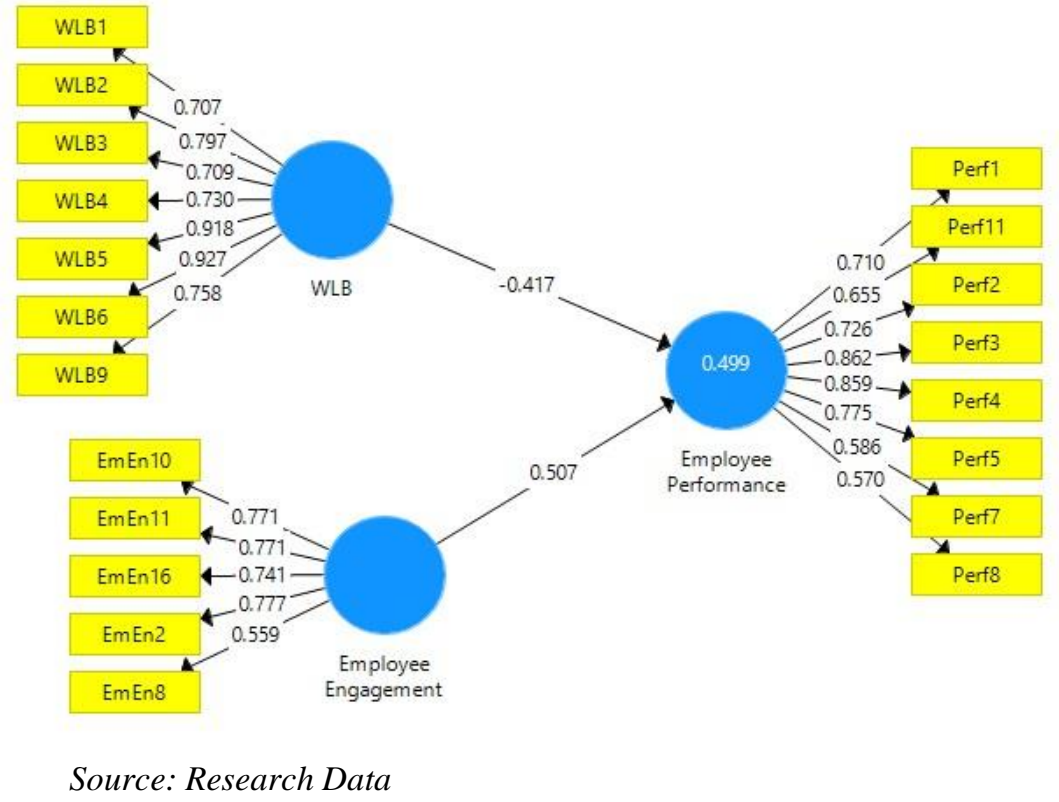

The test for convergent validity using outer loading needs to have a minimum value of 0.5 for each of its indicator (Ghozali and Latan, 2015). The results showed that all variables which are employee engagement, work performance and work - life balance passed the requirement and are considered valid.

Table 2. AVE Result

\begin{tabular}{lcc}
\hline \multicolumn{1}{c}{ Variable } & AVE & Validity \\
\hline Employee engagement & 0.531 & Valid \\
Work performance & 0.526 & Valid \\
Work - life balance & 0.636 & Valid \\
\hline Source: Research Data & &
\end{tabular}

The discriminant validity values for these variables are considered acceptable and therefore the research data was being preceded to the next step.

\section{Table 4. Discriminant Validity Result}

\begin{tabular}{lccc}
\hline & Engagement & Performance & WLB \\
\cline { 1 - 3 } Employee engagement & 0.729 & & \\
\hline Work performance & 0.574 & 0.726 & \\
\hline Work - life balance & -0.160 & -0.498 & 0.797 \\
\hline Source: Research Data & & &
\end{tabular}

The results for composite reliability in this research indicated good results which are shown from all the value scores above 0.7 . 
Table 3. Composite Reliability Result

\begin{tabular}{lcc}
\hline \multicolumn{1}{c}{ Variable } & Composite Reliability & Reliability \\
\hline Employee engagement & 0.848 & Good \\
Work performance & 0.897 & Good \\
Work - life balance & 0.923 & Good \\
\hline Source: Research Data & &
\end{tabular}

The result of multicolinearity test is below 5 which mean the independent variables in this research are not correlated to each other in the equation.

Table 4. Multicolinearity Test

\begin{tabular}{lc}
\hline \multicolumn{1}{c}{ Variable } & Work Performance \\
\hline $\begin{array}{l}\text { Employee } \\
\text { engagement }\end{array}$ & 1.026 \\
Work performance & 1.026 \\
Work - life balance & \\
\hline Source: Research Data &
\end{tabular}

The R square result or the coefficient determinant displays that the construct of work performance explained by its independent variables by the score of $49.9 \%$ and the rest of the remaining percentage could be explained by other variables which are not included in this research model.

Table 5. Coefficient Determination Result

\begin{tabular}{ccc}
\hline \multicolumn{1}{c}{ Construct } & R square & R square adjusted \\
\hline Work performance & 0.499 & 0.489 \\
\hline Source: Research Data & &
\end{tabular}

The result of path analysis is provided as follows:

Table 6. Path Analysis

\begin{tabular}{cccccc}
\hline Path & $\begin{array}{c}\text { Original } \\
\text { Sample } \\
(\mathbf{O})\end{array}$ & $\begin{array}{c}\text { Sample } \\
\text { Mean } \\
(\mathbf{M})\end{array}$ & $\begin{array}{c}\text { Standard } \\
\text { Deviation } \\
(\mathbf{S T D E V})\end{array}$ & $\begin{array}{c}\text { T Statistics } \\
(\mid \mathbf{O} / \mathbf{S T D E V})\end{array}$ & P Values \\
\hline $\begin{array}{c}\text { EE -> } \\
\text { WP }\end{array}$ & 0.507 & 0.443 & 0.264 & 1.918 & 0.056 \\
\hline $\begin{array}{l}\text { WLB }- \\
>\text { WP }\end{array}$ & -0.417 & -0.432 & 0.109 & 3.820 & 0.000 \\
\hline \multicolumn{2}{l}{ Source: Research Data } & & &
\end{tabular}

As presented by the score of $\mathrm{p}$ - values, the work - life balance has a negative significant effect on work performance but the employee engagement bears no significant effect on work performance as indicated by the $\mathrm{p}$ - value result of 0.056 if the confidence interval being used is $95 \%$. However, increasing the significance level to a higher value of .10 or $90 \%$ allows the researcher for having a bigger chance of being wrong but it will also 
become easier to make conclusions that the coefficient is different from the sum of zero (Hair et. al., (2009) which means if this research is using the level significance of $90 \%$ then the employee engagement has an effect on work performance. However, since this research uses 95\% confidence interval, the results of this research conclude that there is no significant effect of employee engagement on work performance and that work - life balance has a negative significant effect on work performance.

Work - life balance (WLB) was found to have a negative significant effect on work performance. The rejection of employee engagement on work performance is considered quite uncommon since many previous research conducted in various fields suggested that employee engagement has an impact of work performance such as the findings from Handoyo and Setiawan (2017), Lewiuci and Mustamu (2016), Astuti et. al., (2016) and Siswono (2016). Nevertheless, this rejected hypothesis is supported by one of the previous research by Aprilian (2013) who found in his research that there was no significant relationship between employee engagements with productive work performance. Work - life balance negatively impacts work performance indicates the inability to obtain sense of balance between fulfilling personal needs and work obligations, which raises the inquiry on whether the two aspects of work - life balance and work performance are contradicting each other as opposed to complementary (Koubova and Buchko, 2013). Previous research done by Burhanudin et. al., (2018) discovered that conflicts arose caused by work - life balance has negative effect on work performance. The imbalance of life quality is linked to poor performance as well as lack of balance on effort and reward (Johari et. al., 2018).

\section{CONCLUSION AND SUGGESTIONS}

Given the unique nature of work - life balance and how each individual perceives it according to their own terms and perceptions, the idea of an increased work performance could be obtained from reducing the working hours is deemed too narrow. The concept of well - being has always been a tricky subject because one's view on balanced life may differ from the others. Thus, any measure of work - life balance should be broad enough to encompass individual's needs and choices. The result of this research, although is not aligned with many of its similar previous studies, is supported by Rochim (2019) who found that work - life balance has negative impact on employees' performance in his study as well as a research conducted by Kim (2014) who found a similar result on his study in Korea where in - role work performance was not positively affected by work - life balance. These findings could be interpreted as proof that different cultures in different countries contribute to various factors which lead to more diverse findings within the same scope. Indonesian culture values moments shared with their family and friends more than time being spent at work (Sat, 2012). Therefore, burden from work might impose an issue on how they manage their time personally and professionally, causing them to lack focus in juggling the two tasks. In big cities such as Jakarta, the demand is steeping high with everything runs at a fast pace which makes it even that more challenging for workers to maintain balance between their personal and professional lives. When being faced with limited time, people have the tendency to choose taking care of their families' affairs and needs first (Pedersen and Lewis, 2012). This 
means even though many employees may spend in average eight hours of their days at work, in the end of the day they would use their extra time to attend to their personal lives and prioritize them first, especially for millennial generations who prefer having good personal life balance over job security (Telegraph, 2018) This notion is backed up by an interesting take from Warren (2015) who posits an idea and puts an emphasis on how in most literatures regarding work - life balance seem to fail to mention financial issues faced by the employees. By common sense, financial restraints should be included in work - life balance indicators and dimensions since most people are forced to make sacrifices in their lives due to financial struggle or needs and this may contribute to how their WLB impacts their work performance. This research also found no significant impact from employee engagement to work performance which is supported by Shimazu et.al., (2018) who found that engagement could be detrimental to in - role work performance. "An old wine in new bottles" is best described for work engagement, which means that the concept of an engaged worker is an old concept being recycled by human resource departments in organizations when dealing with job performance (Macey and Schneider, 2008). Although different types of engagement could be applied such as in a cognitive, physical or emotional aspect but the dimension is usually limited from low to high engagement instead of various dimensions or indicators. This means when it comes to work performance, being engaged is not necessarily required or considered as the main contributor. Another argument for the possible cause of why the employee engagement has no impact on work performance is because the indicators being used were for individual assessment without adding other factors such as from the team work perspective. A study conducted by Torrente et.al., (2012) found that team engagement played a mediating role between work climate and work performance. Collective work engagement is something that can be further examined and studied for future research. The employee engagement is arguably linked to the company's ability in driving all levels of its organization as an aligned and comprehensive unit (Alagaraja and Shuck, 2015) and there is only a limited number of research pertaining work - life balance especially among millennial teachers in Indonesia, with many literatures being done mostly in Western countries according to Butts et. al., (2013) and Casper et. al., (2011). Thus, for future recommendation it is suggested that more research about these variables is needed in order to further develop literatures and test the suitability of the concept in different settings and countries. Building an organizational culture which helps nurture and support work - life balance and employee engagement requires thorough planning and long - term process which involves every aspect of the company's management level. The organization needs to come up with proper planning as to how to get their workers want to become active and contributing members of the company willingly.

\section{REFERENCE}

Abdallah, A. B., Obeidat, B. Y., Aqqad, N. O., Al Janini, M. N. K., \& Dahiyat, S. E. 2017. "An Integrated Model of Job Involvement, Job Satisfaction and Organizational Commitment: A Structural Analysis in Jordan's Banking Sector. Journal Communications and Network. Vol. 9(1), pp: 28 - 53.

Abraham, S. 2012. “Job satisfaction as an antecedent to employee engagement". SIES 
Journal of Management. Vol. 8 (2), pp: $27-36$.

Ahmad, S. (2013). Paradigms of quality of work life. Journal of Human Values, 19 (1), 7382.

Alagaraja, M. and Shuck, B. 2015. "Exploring Organizational Alignment-Employee

Engagement Linkages and Impact on Individual Performance". Human Resource Development Review. Vol. 14(1), pp. 17-37.

Anitha, J. 2014. "Determinants of employee engagement and their impact on employee performance". International Journal of Productivity and Performance Management. Vol. 63 (3), pp: $308-323$.

Anwar, Fahrul. 2017. Engagement Tenaga Kerja Millennial Indonesia Hanya 25\%. [Online] Available: https://youngster.id/featured/engagement-tenaga-kerja-milenialindonesia-hanya-25/. [January 8, 2020].

Asima and Levi, Nilawati. 2016. "Pengaruh Work Life Balance terhadap Kinerja Karyawan yang Dimediasi oleh Komitmen Afektif”. Jurnal Ekonomi dan Pembangunan Universitas Ahmad Dahlan. ISSN: 1411-6022.

Astuti, Putih Luluh Ni, Mimba, Harta Putu Sri dan Ratnadi, Dwi Made Ni. 2016. "Pengaruh Work Engagement pada Kinerja Bendahara Pengeluaran dengan Kepemimpinan Transformasional sebagai Pemoderasi”. E-Jurnal Ekonomi dan Bisnis Universitas Udayana. Vol. 5 (12), pp: $4057-4082$.

Au, W. C., \& Ahmed, P. K. 2014. "Sustainable people management through work-life balance: a study of the Malaysian Chinese context". Asia-Pacific Journal of Business Administration. Vol. 6(3), pp: $262-280$.

Audrey, C.V., \& Patrice, R. 2012. "Adaptive performance: A new scale to measure individual performance in organizations". Canadian Journal of Administrative Sciences. Vol. 29 (2), pp: $280-293$.

Azizah, Azmi and Gustomo, Arik. 2015. "The Influence of Employee Engagement to Employee Performance at PT. Telkom, Bandung”. Journal of Business and Management. Vol. 4 (7), pp: 817 - 829.

Badan Pusat Statistik. 2016. Indonesia Masuk Era Bonus Demografi. [Online] Available: https://databoks.katadata.co.id/datapublish/2016/09/06/indonesia-masuk-era-bonusdemografi-puncaknya-terjadi-pada-2025-2030 [December 18, 2019].

Benito-Osario, D., Muñoz-Aguado, L., \& Villar, C. 2015. "The Impact of Family and WorkLife Balance Policies on the Performance of Spanish Listed Companies". Journal of Management. Vol. 17, pp: 214-236.

Bhatnagar, J. 2014. "Mediator analysis in the management of innovation in Indian knowledge workers: the role of perceived supervisor support, psychological contract, reward and recognition and turnover intention". The International Journal of Human Resource Management. Vol. 25 (10), pp: 1395 - 1416.

Burhanudin, Dewi Trisna, Sjahruddin Herman, Mus Mansyur Abd. 2018. "Pengaruh Konflik Peran Ganda Terhadap Kinerja Melalui Stres Kerja”. Jurnal Organisasi dan Manajemen. Vol. 1(1).

Butts, M. M., Casper, W. J., \& Yang, T. S. 2013. "How important are work-family support policies? A meta-analytic investigation of their effects on employee outcomes". Journal of Applied Psychology. Vol. 98 (1), pp: 1 - 25.

Cappelli. 2014. "Understanding Employee Commitment in the public organizations: A study of the juvenile Detention centre". International Journal of Public Administration. Vol. 18 (4), pp: $126-129$.

Casper, W. J., Harris, C. M., Taylor-Bianco, A., \& Wayne, J. H. 2011. “Work-family 
conflict, perceived supervisor support and organizational commitment among Brazilian professionals". Journal of Vocational Behavior. Vol. 79, pp: 640-652.

Chan, G. 2015. "Part-Time Event Management Employee Expected Quality of Work Life". International Journal of Business and Management. Vol. 10 (5), pp: 233 - 243.

Colquitt, Jason A., Jeffery A. LePine, and Michael J. Wesson. 2015. Organizational Behavior: Improving Performance and Commitment in the Workplace. McGraw - Hill: New York.

Deivasigamani, J. \& Shankar, G. 2014. "A study on work-life balance of employees in information technology (IT) sector at Chennai". International Journal of Management Research and Review. Vol. 4 (4), pp: $805-810$.

Fransiskus, Aprilian. 2013. "Employee Engagement dengan Perilaku Produktif Karyawan”. Jurnal Psikologi Industri dan Organisasi. Vol. 2 (1).

Freddy Arifin, Eka Afnan Troena, Djumahir, Mintarti Rahayu. 2014. "The Influence of Organizational Culture, Leadership, And Personal Characteristics towards Work Engagement and Its Impacts on Teacher's Performance (A Study on Accredited High Schools in Jakarta)". International Journal of Business and Management Invention. Vol. 3 (1), pp: 20 - 29.

French, Katie. 2018. Millennials Prioritizing Work Life Balance Over Job Security, Study Finds. [Online] Available: https://www.telegraph.co.uk/news/2018/11/19/millennialsprioritising-work-life-balance-job-security-applying/ [January 9, 2020].

Ghozali, H. Imam and Hengky Latan. 2015. Partial Least Squares: Konsep, Teknik dan Aplikasi Menggunakan Program Smart PLS 3.0 untuk Penelitian Empiris. Badan Penerbit - Undip: Semarang.

Haar, J. M., Russo, M., Suñe, A. \& Ollier Malaterre, A. 2014. "Outcomes of Work - life Balance on Job Satisfaction, Life Satisfaction and Mental Health: A Study across Seven Cultures". Journal of Vocational Behavior. Vol. 85 (3), pp: 363 - 373.

Hair Jr., J.F., Black, W.C., Babin, B.J. and Anderson, R.E. 2009. Multivariate Data Analysis. 7th Edition. Prentice Hall, Upper Saddle River: New Jersey.

Handoyo W.A. and Setiawan, R. 2017. "Pengaruh Employee Engagement Terhadap Kinerja Karyawan Pada PT. Tirta Rejeki Dewata”. Jurnal Agora. Vol. 5 (1).

Helmle, J. R., Botero, I. C., \& Seibold, D. R. 2014. "Factors that influence perceptions of work - life balance in owners of firms". Journal of Family Business Management. Vol. 4 (2), pp: $110-132$.

Hye Kyoung Kim. 2014. "Work-Life Balance and Employees' Performance: The Mediating Role of Affective Commitment”. Global Business and Management Research: An International Journal. Vol. 6 (1).

Ischevell, Vialara Saina, Riane and Johnly, W. Rumawa. 2016. "Pengaruh Work - Life Balance dan Kompensasi terhadap Kinerja Karyawan pada PT. PLN Wilayah Sulutenggo, Manado". Jurnal Administrasi Bisnis. Vol. 4 (3).

Jenkins, Ryan. 2018. This is Why Millennials Care So Much about Work Life Balance.

[Online] Available: https://www.inc.com/ryan-jenkins/this-is-what-millennials-valuemost-in-a-job-why.html. [December 28, 2019].

Jobstreet.co.id. 2014. 73\% Karyawan Tidak Puas dengan Pekerjaan Mereka. [Online]

Available: https://www.jobstreet.co.id/career-resources/73-karyawan-tidak-puasdengan-pekerjaan-mereka/\#.XiRpZsgzbIU [November 29, 2019].

Johari, J., Yean Tan, F., \& Tjik Zulkarnain, Z. I. 2018. "Autonomy, workload, worklife balance and job performance among teachers". International Journal of Educational Management. Vol. 32 (1), pp: 107 - 120.

Joo, B. K., and Lee, I. 2017. “Workplace happiness: work engagement, career satisfaction, 
and subjective well - being”. A Global Forum for Empirical Scholarship. Vol. 5 (2), pp: 206-221.

Jose, G., \& Mampilly, S. R. 2012. "Satisfaction with HR practices and employee engagement: A social exchange perspective". Journal of Economic and Behavioral Studies. Vol. 4 (7), pp: 423 - 430.

Joushan, Shindie Aulia., Syamsun, Muhammad., and Kartika, Lindawati. 2015. "Pengaruh Budaya Organisasi dan Employee Engagement Terhadap Kinerja Karyawan pada PT PLN (Persero) Area Bekasi”. Jurnal Aplikasi Manajemen. Vol. 13 (4).

Juniman, Trimeni Puput. 2018. Studi: Millennial Lebih Stres di Kantor Dibanding Usia Lain. [Online] Available: https://www.cnnindonesia.com/gaya-hidup/20180604114519282-303202/studi-milenial-lebih-stres-di-kantor-dibanding-usia-lain [January 9, 2020].

Kahn, W.A. 1990. "Psychological conditions of personal engagement and disengagement at work”. Academy of Management Journal. Vol. 33, pp: 692 - 724.

Kemenkes RI. 2018. Riset Kesehatan Dasar 2018. Badan Penelitian dan Pengembangan Kesehatan: Jakarta.

Kishino, S. and Hirano. 2016. The Effect of Supervisors Transformational Leader on Subordinates Psychological Empowerment and Work-Life Balance. Unpublished, Dissertation. Japan: Kobe University.

Koopmans, L., Berhnaards, C.M., Hildebrandt, V.H., Vet, H.C.W., \& Berk, A.J. 2014. "Construct validity of the individual work performance questionnaire". Journal of Occupational and Environmental Medicine. Vol. 56 (3), pp: 154 - 171.

Kourdi, Jeremy. 2009. 100 Great Business ldeas. Marshall Carvendish lnternational: Singapore.

Kumara, J., \& Fasana, S. F. 2018. "Work - life conflict and its impact on turnover intention of employees: The mediation role of job satisfaction”. International Journal of Scientific and Research Publications. Vol. 8 (4), pp: $478-484$.

Lewiuci G. P. and Mustamu, H.R. 2016. "Pengaruh Employee Engagement Terhadap Kinerja Karyawan Pada Perusahaan Keluarga Produsen Senapan Angin”. Jurnal AGORA. Vol. 4 (2), pp: $101-107$.

Macey, W. H. and Schneider, B. 2008. "The meaning of employee engagement”. Industrial and Organizational Psychology: Perspectives on Science and Practice. Vol. 1 (1), pp: $1-30$.

Maylett, Tracy \& Paul Warner. 2014. MAGIC: Five Keys to Unlock the Power of Employee Engagement. Decision Wise, Inc.: Texas.

Moody, Bill. 2017. Study Finds Employee Engagement Critical to Fixing the Financial Industry. [Online] Available: https://www.businesswire.com/ news/home/ $20170515005127 /$ en/Study-Finds-Employee-Engagement-Critical-Fixing-Financial [January 8, 2020].

Musgrove, C., Ellinger, A. E., and Ellinger, A.D. 2014. "Examining the influence of strategic profit emphasis on employee engagement and service climate". Journal of Workplace Learning. Vol. 26, pp: $152-171$.

Nurwahyuni, Siti. 2019. "Pengaruh Beban Kerja terhadap Kinerja Karyawan melalui Work - Life Balance (Studi Kasus PT. Telkom Indonesia Regional V”. Jurnal Ilmu Manajemen Universitas Negeri Surabaya. Vol. 7 (1).

Pandey, D. B. and Jha, B. K. 2015. "Review and Redefine: Quality of Work Life for Higher Education”. Global Journal of Management And Business Research. Vol. 14 (11), pp: $34-41$.

Pedersen, V. B. and Lewis, S. 2012. "Flexible friends? Flexible working time arrangements, 
blurred work-life boundaries and friendship". SAGE Journal Work, Employment and Society. Vol. 26 (3), pp: $464-480$.

Putra, Manggala Yudha. 2020. Sensus Penduduk 2020, Sensus Era Digital. [Online] Available: https://republika.co.id/berita/q3qglj284/sensus-penduduk-2020-sensusera-digital [January 18, 2020].

Ramadhan dan Sembiring, Jafar. 2014. "Pengaruh Employee Engagement terhadap Kinerja Karyawan di Human Capital Center PT. Telekomunikasi Indonesia, Tbk". Jurnal Manajemen Indonesia. Vol. 14 (1).

Riset Kesehatan Dasar Depkes RI. 2018. Riset Kesehatan Dasar Tahun 2018. Badan Penelitian dan Pengembangan Kesehatan Republik Indonesia: Jakarta.

Robbins, P. Stephen dan Mary Coulter. 2010. Manajemen. Erlangga:Jakarta.

Rochim, Sidik. 2019. "Pengaruh Kemampuan, Work - Life Balance, Kepuasan Kerja terhadap Kinerja pada Karyawan BMT Permata Jawa Timur”. Yos Soedarso Economics Journal. Vol. 1 (1). ISSN 2684-9720 20.

Romahdona, Rizki Jimmi and Palupiningdyah. 2015. "Pengaruh Work - Life Balance pada In - Role Performance dengan Affective Commitment sebagai Variabel Mediasi”. Management Analysis Journal. Vol. 4 (1).

Sat. 2012. Indonesians concerned about work-life balance: Survey, The Jakarta Post.

[Online] Available: http://www.thejakartapost.com/news/2012/10/31/indonesiansconcernedabout-work-life-balance-survey.html [December 28, 2019].

Schepers, J.M. 2011. "The construction and evaluation of a generic work performance questionnaire for use with administrative and operational staff”. SA Journal of Industrial Psychology. Vol. 34 (1), pp: $10-22$.

Shaffer, M. A., Sebastian Reiche, B., Dimitrova, M., Lazarova, M., Chen, S., Westman, M., \& Wurtz, O. 2016. "Work and family role adjustment of different types of global professionals: Scale development and validation”. Journal of International Business Studies. Vol. 47 (2), pp: 113 - 139.

Shimazu A, Schaufeli WB, Kubota K, Watanabe K and Kawakami, N. 2018. "Is too much work engagement detrimental? Linear or curvilinear effects on mental health and job performance”. Journal PloS ONE. Vol. 13 (12).

Siswono D. 2016. "Pengaruh Employee Engagement Terhadap Kinerja Karyawan di Rodex Travel Surabaya”. Jurnal Agora. Vol. 2 (4), pp: 374 - 380.

Sugiyono. 2016. Metode Penelitian Kuantitatif, Kualitatif dan Kombinasi (Mixed Methods), 8th ed. Alfabeta: Bandung.

Thevanes, N and Mangaleswaran. 2018. "Relationship between Work - Life Balance and Job Performance of Employees". IOSR Journal of Business and Management (IOSRJBM). Vol. 12 (5), pp: $11-16$.

Torrente, P., Salanova, M., Llorens, S., \& Schaufeli, W.B. 2012. "Teams make it work: How team work engagement mediates between social resources and performance in teams". Psicotema. Vol. 24, pp: 106 - 112.

Tsai, Y.-H.et al., 2016. "Work hours and turnover intention among hospital physicians in

Taiwan: does income matter?”. BMC Health Services Research. Vol. 16 (1), pp: 1 - 8.

Veronika Koubova and Aaron A. Buchko. 2013. Life-work balance Emotional intelligence as a crucial component of achieving both personal life and work performance. Unpublished. Illinois: Department of Business Management and Administration, Foster College of Business, Bradley University.

Warren, T. 2015. "Work-life balance/imbalance: the dominance of the middle class and the neglect of the working class". British Journal of Sociology. Vol. 66 (4), pp: 691 717. 
Yudi, Muliawan, Badia, Perizade \& Afriyadi, Cahyadi. 2017. "Pengaruh Keterikatan Karyawan (Employee Engagement) terhadap Kinerja Karyawan di PT. Badja Baru Palembang". Jurnal Ilmiah Manajemen Bisnis Dan Terapan. Vol. 15 (2).

Zhang, M., Griffeth, R. W and Fried, D. D. 2012. "Work - family conflict and individual consequences". Journal of Managerial Psychology. [Online] Available: https://doi.org/10.1108/02683941211259520 [January 8, 2020].

Zheng, C., Molineux, J., Mirshekary, S. and Scarparo, S., 2015. "Developing individual and organisational work - life balance strategies to improve employee health and well being”. Journal of Employee Relations. Vol. 37 (3), pp: 354 - 379. 